\title{
Beyond hegemony: Elaborating on the use of Gramscian concepts in Critical Discourse Analysis for Political Studies ${ }^{1}$
}

\author{
Matthew Donoghue \\ Department of Social Policy and Intervention, University of Oxford
}

\begin{abstract}
The work of Antonio Gramsci is important to the theoretical underpinnings of Critical Discourse Analysis (CDA). However, many scholars' engagement with Gramsci's work within CDA remains surprisingly thin. This article seeks to highlight the detriment to CDA of having only a surface engagement with Gramsci. It critically assesses how Gramscian concepts such as hegemony and 'common sense' are currently employed within CDA, and provides more detailed discussion on the import of these concepts for CDA. The article also argues that introducing the Gramscian concepts of the war of position and spontaneous and normative grammars enable the further realisation of CDA's ambition to be an emancipatory tool in political and social science. In so doing, the article contributes to work on CDA as a method in political studies, particularly concerning the role of discourse in reproducing and maintaining asymmetrical power relations between classes and social groups, and potential challenges to this.
\end{abstract}

Keywords: Gramsci, Discourse, Hegemony, Common sense, methodology

\section{Introduction}

Critical Discourse Analysis (CDA) engages with and critiques power relations in text and talk (Van Dijk, 2004, p. 352). It is a powerful tool in problematising constructions of language that (re)produce asymmetrical power relations between ruling and subaltern classes. It is rooted in critical social theory, drawing from thinkers such as Foucault, Bourdieu, Gramsci, Althusser, and the Frankfurt School (Luke, 2002).

CDA's flexibility - it can be combined with various methods, used in various disciplines, and can take different forms - is partially due to this broad theoretical heritage, but also due to CDA's explicitly socially situated nature, taking inspiration from many people and directions of research (Van Dijk, 2001, p. 95). However, a drawback is that its theoretical underpinnings and frameworks can become blurred; the invocation of theorists with potentially conflicting nuances can cause tensions in how the object of study is approached and analysed. 'Given the striking heterogeneity of CDA's intellectual sources, it is at least surprising that there is little debate within CDA circles about their relevance or, indeed, their compatibility' (Breeze, 2011, p. 501), suggesting some uncertainty regarding CDA's 'exact preferences for a particular social theory' (Slembrouck, 2001, pp. 40-41). Indeed, van Dijk (2003, p. 363) - a central scholar of CDA - admits that 'the multidisciplinary theory of CDA that should relate discourse and action with cognition and society are still on the agenda'. Relatedly, in many cases thinkers and theories are referenced without much in the way of explanation or elaboration on the position, use and significance of their conceptual contributions. CDA's invocation of Antonio Gramsci is exemplary of this.

\footnotetext{
${ }^{1}$ I am grateful for the incisive comments provided by Dr. Chris Hesketh and Dr. Ben Whitham on earlier drafts of this article. My thanks too to colleagues from the Department of Social Policy and Intervention for their comments.
} 
Gramscian concepts - noticeably hegemony, but to a lesser extent common sense - are referenced regularly when situating CDA theoretically. However, notwithstanding notable exceptions (Fairclough, 2004; 2013), those that draw on Gramsci for their inspiration in many cases provide scant details. In this article, I argue that not providing a more in-depth assessment of Gramscian thought in the context of discourse hinders the development of a potentially very useful framework within which to situate CDA. In particular, I argue that a greater engagement with Gramsci's work on hegemony and common sense, whilst also introducing more firmly the concepts of war of position and normative and spontaneous grammars, bolsters the analysis of the relationship between social relations and discourse, and also strengthens CDA's claim as a tool for social critique and emancipation (Wodak and Meyer, 2009, p. 7). Gaining a deeper understanding of hegemony and common sense, with a fuller appreciation of the mechanisms of coercion and consent, can only be attained with a deeper engagement with Gramsci's work. This article therefore makes an original contribution by providing this fuller engagement explicitly within the context of CDA, which is largely missing in the current literature. Furthermore, the introduction of the War of Position and of normative and spontaneous grammars deepens further our understanding of the cogs within the machinery of hegemony, and gives more explanatory power to the notion of common sense as a central element of hegemony as well as an element over which groups struggle for control. The article thus provides another contribution in sketching out the relationship between these concepts and how their interaction impacts upon the development, influence and sites of vulnerability of discourse as a tool of social and political domination.

Emphasising the contribution Gramsci can make to CDA increases the approach's relevance for political studies and analysis. It enables CDA to say more regarding state and power maintenance through power relations between state, citizen and civil society. It also provides a robust critical framework from which to analyse ideological assumptions inherent within political and policy decisions, and their impact on citizens' political and social participation.

The article is divided into a number of sections. The first section explores shared underpinnings between CDA and Gramscian theory. Next, the article reviews how Gramsci is invoked in existing CDA literature. Section three engages with the Gramscian concepts of war of position and normative and spontaneous grammars, outlining their use in CDA and how they can strengthen the relationship between discourse and hegemony. Finally, the article concludes.

\section{Shared underpinnings}

CDA draws upon many theorists including Gramsci. Yet the cursory approach to Gramsci's work is particularly evident with regards to scholars' treatment of the concepts of hegemony and common sense. It is important to remember that

A linguistic and text analytic metalanguage, no matter how comprehensive, cannot "do" CDA in and of itself. It requires the overlay of social theoretic discourses for 
explaining and explicating the social contexts, concomitants, contingencies and consequences of any given text or discourse (Luke, 2002, p. 102).

Gramsci's work in particular provides a solid foundation for such theorising. This is because 'for Gramsci language is both an element in the exercise of power and a metaphor for how power operates' (Ives, 2004, p. 101). Power in language can be seen in the ways in which debate is opened up or shut down in various discourses (e.g. Donoghue, 2013), voices included or excluded (e.g. van Zoonen, 1994) or its role in the production of physical violence (e.g. Linell and Jonsson, 1991). Language acts as a metaphor for power because inherent to language use (and abuse) is a framework of rules. These rules guide how we understand the social and political worlds and thus in turn how we act and interact within those worlds. These rules, how they develop, how they act upon different groups, and how they can be challenged is the central broad concern of CDA (van Dijk, 2003, p. 352).

At its core, a discourse analytical approach considers social reality to be constructed through social interaction (Phillips and Hardy, 2002). This is represented in discourses, which are 'the interrelated texts, conversations and practices associated with a particular object' (Burnham et al., 2008, p. 250). Some have suggested that the primacy of social constructionism within discourse studies in general precludes a more extensive use of Gramsci because of his primarily materialist position. De Goede (2003, p.90; cited in Bieler and Morton, 2008, p. 105) for example argues that Gramscian political analysis is economistic: discourse and culture, as part of the superstructure, are secondary in importance to the economic base 'which ultimately determines the objective economic interests of agents'. However, this criticism is misplaced for a number of reasons. Firstly, Gramsci is widely heralded as central to the cultural turn in Marxism precisely because of the importance he placed on elements other than the economy and capital, whilst still retaining a deep and extensive critique of the material and ideational aspects of capitalism (Crehan, 2002, pp. 71-91; Jessop and Oosterlynck, 2008). Laclau (2005, p. 116) goes further, arguing that Gramscianism represents 'a crucial epistemological break' within Marxism because it 'breaks decisively with [traditional Marxism's] essentialist social logic'. Gramsci saw neither the economic base nor the ideational superstructure as necessarily prior to the other. Rather he conceived 'their development as intimately bound together and necessarily interrelated and reciprocal' (Gramsci, 1995, p. 414). In other words, Gramsci's interest in emphasising culture and ideas was in order to better understand not only the influence and strength of the economic base, but also 'the dialectical way ideas prevail in interrelationship with material properties' (Bieler and Morton, 2008, p. 105).

The importance of the relationship between the ideational and the material, rather than the primacy of one over the other, is what makes Gramsci's epistemology so compatible with CDA. Norman Fairclough, for example, argues that CDA is 'based upon a view of semiosis as an irreducible part of material social processes' (Fairclough, 2001, p. 122). CDA's epistemology is also centred on the relationship between the ideational and material. Fairclough further argues that certain forms of meaning arise and are given strength through the creation of social identities that form from the relationship between social processes and forces of production (Fairclough, 2001, p. 122). These positions appear 
immutable, because meaning is experienced as humanly objective whilst being historically subjective, reflecting the material conditions and social relations in a given historical moment (Gramsci, 1971, p. 445). These positions and meanings do not simply disappear from one historical moment to the next, but become involved in a 'continual process of metaphor' (Ives, 2005, p. 463). In other words these ideas become embedded within the concrete material relations of the time, framing our understanding of those relations.

This continual process gives rise to dominant discourses; the primary frames through which our understandings of social relations and material conditions develop. Van Dijk argues that from a CDA perspective, a major function of dominant discourses is to manufacture 'consensus, acceptance and legitimacy of dominance' (Van Dijk, 1993 p. 255), whilst CDA itself studies, critiques and exposes the discursive reproduction of this dominance (Van Dijk, 1993, p. 259). However, these discourses must also be constructed, or the terrain must be made fertile for particular discourses to become dominant. From a Gramscian position, this suggests that discourses play a role in the development and maintenance of hegemony. Discourses contribute to the construction of a hegemonic project, which requires social unity in favour of the dominant class. This is built partially through the organisation of common sense (Ives, 2005, pp. 74-75), which allows for the construction of an historical bloc that exerts moral, intellectual and political leadership (Jessop, 1997). This bloc can only rise if both the material and ideational conditions are favourable. Indeed, it is the ideational conditions that legitimise the existence of the bloc, which gives it greater control over the material conditions of the time. Though blocs are undoubtedly important, they are not the primary focus of analysis in CDA. Rather, considering that CDA is intimately concerned with how groups marshal and control social power (van Dijk, 2003, p. 354), focus is on how the emergence and dominance of particular discourses help some blocs consolidate their power over others.

A central mechanism for this in both Gramsci and CDA is common sense, seen as the internalisation and normalisation of a particular worldview, which takes subjective positions and makes them innocuous and therefore unquestioned. Yet, as I will demonstrate later the mechanics go much deeper than this, as does its relationship with hegemony and components such as spontaneous and normative grammar (Ives, 1997; 2004; 2005).

The mechanics of common sense imply a relationship between coercion and consent, a key pillar of hegemony (Jones, 2006, p. 49). Coercion is generally associated with apparatuses of control and enforcement, whilst consent is built through civil society. The state needs to retain control over its citizens, whilst also encouraging citizens to freely provide their consent without feeling directly coerced. The importance of discourse to this process should be clear for two reasons. Firstly because '[a] social class cannot convince others of the validity of its world view until it is fully convinced itself' (Bates, 1975, p. 355), highlighting the centrality of common sense both within and beyond an hegemonic bloc, uniting disparate elements. Secondly 'for Gramsci, common sense cannot be eliminated but is "what is at stake in the struggle for hegemony". The transformation of subalternity requires not the elimination of common sense but the critique and transformation of it' (Green and Ives, 2009, p. 8). Organising discourse to effect spontaneous consent echoes the position 
that "many forms of dominance appear to be "jointly produced" through intricate forms of social interaction, communication and discourse' (Van Dijk, 1993, p. 255). This emphasises hegemony as 'the connection between the ways in which social consciousness are formed and the exercise of political (or class) rule under conditions of high levels of popular consent' (Hunt, 1990, pp. 310-11).

The concept of hegemony is therefore central to any use of Gramsci within CDA, not least because the linguistic-discursive component of hegemony is inherently linked with common sense (Ives, 2006). The body of work covering the concept of hegemony is expansive (e.g. Kincheloe and McLaren, 2002, p. 93; Rupert, 2003; Thomas, 2013; Morton, 2007; Leggett, 2009 , p. 140); this article cannot do the full canon justice. A key point to remember, however, is that hegemony is constructed via dialectical processes between the material and socio-cultural. It is not simply about physical domination. Rather, "hegemony includes the creation of a "collective will" - not merely an economic class coming into its own or becoming aware of itself - but the construction of a social-cultural unity' (Ives, 2005, p. 458 - second emphasis added). This is emphasised by Jessop (1990, p. 162): 'the greater the capacity of capitalist spokesmen in civil society to elaborate a coherent accumulation strategy and couple it with an attractive hegemonic project, the less need there will be for a strong, centralised system to act in relatively autonomous fashion for, and on behalf of, capital'. Hegemony is thus the promotion and dominance of a particular set of ideas through the construction of a socio-cultural unity developed through both material and ideational struggles. This can be directly related to the arguments of CDA scholars such as Fairclough (1985) and Van Dijk that discourses (re)produce structures of dominance through 'subtle, routine, everyday forms of text and talk that appear "natural" and quite "acceptable"' (Van Dijk, 1993, p. 254). As will be demonstrated later, this can be seen in the mechanics of normative and spontaneous grammar.

Blommaert and Bulcaen (2000, p. 449) state that hegemony is achieved through 'forming alliances and integrating classes through consent', referencing Fairclough's position that 'the articulation and rearticulation of orders of discourse is correspondingly one stake in hegemonic struggle' (Fairclough, 1992, p. 93). At its heart, then, discourse according to CDA is a site of struggle as well as a tool of dominance. The notion of struggling within and over discourse links to Gramsci through the War of Position. This, for Gramsci, is the struggle that must take place to create the political and ideological conditions necessary for the War of Manoeuvre, (Gramsci, 1971, p. 243). Here, discourse can be understood as one component within a wider ideational and material struggle. Struggles over and of discourse form a major component of the war of position, considering its significant ideological dimension.

Thus, Gramsci's thought is ideally placed for developing a theoretical framework within which to situate CDA. However, considering the seeming importance of Gramsci's thought in critical discursive endeavours, it is striking that firstly key concepts such as common sense, are not engaged with in more detail despite being referenced prolifically. Using a discursive and linguistic understanding of hegemony as a jumping off point, the next section discusses how Gramscian concepts are employed in CDA.

\section{Common uses of Gramsci in CDA}


Despite the importance of shared underpinnings, these are not always particularly wellarticulated in CDA's theoretical frameworks. By and large, when Gramsci is cited, it is only in a cursory fashion - even though a more thorough engagement with his thought provides an ideal framework within which to situate a critical analysis of power relations within language.

Norman Fairclough, perhaps CDA's best-known scholar, has done the most to incorporate more fully the work of Gramsci into a framework for CDA (Jorgensen and Phillips, 2002, p. 75). As such Fairclough's work is well cited in this article. This is not to suggest that CDA as a whole should be confined to Fairclough's development of it. Yet Fairclough's development of CDA has been particularly influential, and contains perhaps the most developed incorporation of Gramsci's thought. This provides further justification for a closer reading, whilst not underestimating the contribution of scholars such as Wodak, van Dijk and Blommaert, for example.

As discussed in the previous section, the notion of hegemony is central to Fairclough's conceptualisation of discourse construction as a struggle. Indeed, 'Gramsci's observation that the maintenance of contemporary power rests not only on coercive force but also on "hegemony" (winning the consent of the majority) has been particularly influential in CDA' (Fairclough et al., 2011, p. 360). Yet the concept is largely treated as a given rather than unpacked. This seems to go against a key principle of CDA as a dialectical method, whilst also obscuring the potential to reveal in analysis a multitude of further ways of identifying, analysing and problematising power relations as manifested in language. As Sassoon argues:

It is important to situate hegemony as belonging to a cluster of words [...] the reference points of which keep shifting and/or mean more than one thing, partly because of historical changes which have already taken place, and partly because processes are underway, according to Gramsci, which make possible the subversion and transformation of politics (Sassoon, 2000, p. 45).

CDA's use of concepts and terms should be subject to critical assessment within themselves. Such treatment could increase further CDA's reflexivity, in turn providing further potential combinations with other critical political analysis. Current understandings of hegemony however simply employ it as a primarily descriptive (albeit theoretically informed) tool to suggest domination via consent (van Dijk, 1993, p. 255; 259), which prioritises theoretical convenience over depth. Another example from Fairclough helps illustrate this argument further.

Fairclough employs the concept of hegemony a number of times in Analysing Discourse, but without particularly strict analytical treatment. He characterises it as 'a particular way of conceptualising power which amongst other things emphasises how power depends upon achieving consent or at least acquiescence rather than just having the resources to use force, and the importance of ideology in sustaining relations of power' (Fairclough, 2003, p. 45). He sees it as a process that universalises the particular, so that 'universal claims are made for one view... amongst others' (Fairclough, 2003, p. 46). Here, the focus remains on 
the notion of hegemony as struggle for domination, rather than a form of domination through coercion and consent:

Hegemony is a focus of constant struggle around points of greatest instability between classes and blocs, to construct or sustain or fracture alliances and relations of domination/subordination, which takes economic, political and ideological forms. Hegemonic struggle takes place on a broad front which includes the institutions of civil society (education, trade unions, family), with possible unevenness between different levels and domains (Fairclough, 2013, pp. 61-62).

Blommaert provides a caveat to the general use of hegemony in CDA. He argues that it is remarkable how often hegemony is interpreted as generalised, even internalised, consent' (Blommaert, 2005, pp. 166-167), highlighting the tendency to remove or marginalise the notion of coercion from discursive analytic invocations of hegemony. Yet the generation of 'spontaneous' consent in hegemony hinges upon coercion. 'Spontaneous' equates broadly to free will, with the understanding that what is presented as objective rational freedom is in fact socially, historically and politically contingent. Consent is 'given by the great masses of the population to the general direction imposed on social life by the dominant fundamental group' because of 'the prestige (and consequent confidence) which the dominant group enjoys because of its position and function in the world of production' (Gramsci, 1971, p. 12). Thus consent is 'spontaneous' because it is a naturalised result of the relations of force, and power relations between the elite and the subaltern. It does not appear out of thin air, or through unencumbered public agency. Individuals and groups become responsible for policing one another's adherence to the status quo. For example, if someone 'carries [others' directives] out, he makes certain that others are carrying them out too; if, having understood their spirit, he propagates them as though making them into rules specifically applicable to limited and definite zones of living' (Gramsci, 1971, p 266).

Spontaneous consent, then, relies on its relationship to coercion, or the potential for its use. This understanding can become marginalised if one emphasises too much the notion of 'discursive and extra-discursive' in which 'reality' is understood as the material level of practices (Hook, 2001), or that 'everything is discourse' (Luke, 2002, p. 103; 1997). This was perhaps most prominently asserted in relation to discourse in Laclau and Mouffe's Hegemony and Socialist Strategy. They argue that whether or not there is an external, material world that acts upon discourse is of no concern because objects cannot be understood or conceived of without discourse (Laclau and Mouffe, 2001, p. 108). This places discourse prior to the material, where instead a critical, Gramscian approach would understand the relationship between discourse and the material to be dialectical. Though Laclau's later work develops the concept of hegemony much further, it retains the broad position found in Hegemony and Socialist Strategy. Hegemony is understood as inherently contingent because it is 'the representation of a mythical totality' that suggests total control based on a much more partial form of dominance (which is why it can be seen as a site of struggle). If hegemony was 'a systemic totality', it 'would require no investment and no hegemony' (Laclau, 2005, p. 116). Discursively, this makes sense - the issue under question is how discourse contributes to the development of hegemony and the legitimacy of a 
hegemonic bloc. Yet it is crucial that hegemony is not seen as taking place purely on the terrain of discourse. As I will demonstrate when discussing the war of position, the discursive element of hegemony is of central importance, but it is only one element in a much larger complex.

Scholars such as Fairclough and Bob Jessop have worked on treading a middle ground between these positions. Fairclough et al. (2004, p. 23) remark in a discussion of critical realism and semiosis, that it may be appropriate to 'supplement [CDA] through more concrete-complex analyses of extra-discursive domains'. Jessop argues that the totality of economic activities is inherently unstructured and complex and therefore needs to be discursively fixed. "This involves "economic imaginaries" that rely on semiosis to constitute these subsets', and if these imaginaries are to be more than 'arbitrary, rationalistic and willed' (Gramsci, 1971, pp. 376-377; cited in Jessop, 2004, p. 162) they 'must have some significant, albeit necessarily partial, correspondence to real material interdependencies in the actually existing economy' (Jessop, 2004, p. 162). These calls to include further focus on the relationship between the ideational and the material lend further credence to this paper's core argument: that a deeper and explicit engagement with Gramsci's concepts of hegemony, common sense, and the introduction of the war of position and spontaneous and normative grammars, provides CDA with increased explanatory and critical power, enabling it to extend its analysis of material conditions, via the significance and dominance of particular discourses.

This requires emphasising Gramsci's philosophy of praxis - which, in discursive terms is the interrogation and critique of orthodox thought and received wisdom. This is essential to understanding a Gramscian treatment of language and discourse exactly because Gramsci's analysis of language and social relations were intimately tied to questions of political organisation and struggle' (Green and Ives, 2009, p. 8). This is illustrated by Gramsci himself who remarks that '"popular beliefs" and similar ideas are themselves material forces' (Gramsci, 1971, p. 165).

The struggle to organise and control the (re)production and leigitmisation of discourse, as well as to maximise the political impact of a well organised discursive construct, is undoubtedly central to any broadly Gramscian understanding or implementation of CDA. Luke, following Fairclough (1992), argues that discourse has a hegemonic function, it works to 'naturalise its own functions through its appearance in everyday texts', and that 'the texts of everyday life involve overlapping discourses that are articulated, rearticulated, and, at times, disarticulated in particular hegemonic interests' (Luke, 1995, p. 20). Luke also argues that much CDA scholarship can become stuck on interpreting text without situating it sociopolitically or it can have trouble relating the analysis of text and discourse to this context (Luke, 2002, pp. 101-102). Engaging with common sense further helps address some of these concerns.

The Gramscian usage of common sense is evident in some CDA literature although, as with hegemony, it is seldom comprehensively unpacked. This is perhaps unsurprising, considering that common sense can be understood as a key linguistic element of hegemony, and to deal with common sense in detail first requires the unpacking of hegemony. The 
concept as directly related to CDA is found to the greatest extent again in Fairclough's work. Fairclough understands common sense in broadly Gramscian terms, as the naturalisation or autonomisation of ideologies, as well as a 'depositary of the diverse effects of past ideological struggles, and a constant target for restructuring, in ongoing struggles' (Fairclough, 2013, p. 62). Locke, taking from Wodak (2001, p. 6; 3) and Van Dijk (1993, p. 254), understands common sense to be simply the naturalisation of discourse (Locke, 2004, p. 32).

Fairclough mentions that 'a particular social structuring of semiotic difference may become hegemonic, become part of the legitimising common sense which sustains relations of domination' (Fairclough, 2001, p. 124). Elsewhere he remarks that '[n]aturalisation gives to particular ideological representations the status of common sense, and thereby makes them opaque, i.e. no longer visible as ideologies' (Fairclough, 2013, p. 44); that ideology works by 'disguising its ideological nature. It becomes naturalised, automatized - "common sense" in Gramsci's terms' (Fairclough, 2013, p. 67). Following Fairclough (1989), Gough and Talbot (1996, p. 226) characterise common sense as unquestioned assumptions about the social world. Fowler (1996, p. 11) understands common sense as a series of implicit beliefs that provide a normative base to discourse. Van Dijk (2006, p. 117) remarks that '[s]ometimes, ideologies become shared so widely that they seem to have become part of the generally accepted attitudes of an entire community, as obvious beliefs or opinion, or common sense'.

Of course, none of these understandings are 'wrong'. However, they do assume that the naturalisation of a position is the sole process of common sense, and that process comes about relatively unproblematically, or at most through an amorphous 'struggle'. The use of the term remains descriptive. Perhaps more problematically, these understandings of common sense outlined above are perilously similar to Fairclough's understanding of hegemony as a process in which 'universal claims are made for one view' (Fairclough, 2003, p. 45). Although not entirely identical, hegemony and common sense are nonetheless conflated as two concepts that essentially do the same thing, rather than as interrelated concepts whereby one strengthens the other. If they are understood as more or less the same, is there a need to reference both in the first place? The fact such conflations occur highlights the rather shallow treatment of Gramsci's concepts, and strengthens the argument that a deeper investigation of the utility of Gramscian concepts within CDA is warranted. This is especially important because common sense can be taken as a central process within the construction of (and struggle for) hegemony. The conflation of hegemony and common sense removes a significant element in understanding how particular discourses become dominant, and how this dominance contributes to the ability for powerful social groups to consolidate their position in society. It is therefore crucial that common sense is understood firstly as a concept in its own right, and secondly as an essential mechanism of hegemony. This simply is not possible with the commonly accepted reading of the concepts in the majority of the CDA literature. This diminishes CDA's emancipatory potential (e.g. Chilton and Wodak, 2005) because it weakens the approach's ability to interrogate discourse as a tool for the consolidation and abuse of power (van Dijk, 2004, p. 352). 
Common sense in Gramsci is the 'average' worldview of a population, as opposed to the English understanding of common sense as 'good', or uncomplicated, sense. It is contingent on a multiplicity of ideas, images, facts and assumptions and 'could become a ground of struggle because it is an amalgam of historically effective ideologies, scientific doctrines and social mythologies' (Rupert, 2003, p. 185). Capturing the common sense of a nation in a particular historical moment involves organising it so that particular discourses become dominant and unquestioned - the process of naturalisation discussed by Fairclough and Locke. This is possible because common sense is 'a chaotic aggregate of disparate conceptions, and one can find there anything that one likes' (Gramsci, 1971, p. 422). These conceptions are 'fragmentary and contradictory, open to multiple interpretations and potentially supportive of very different kinds of social visions and political projects' (Rupert, 2003, p. 185). This treatment of common sense obviously goes further than simply being the naturalisation of discourse, and even Fairclough's understanding of it being a depository of past struggles. It also stands in contrast to Fairclough's designation of hegemony as a 'focus of constant struggle'. Although 'hegemony', broadly conceived, is certainly a site of struggle, it is usually between hegemonic and (potentially) counter-hegemonic blocs; between the ruling class and the subaltern (of which both include multiple smaller blocs and groupings). In a discursive sense there is a struggle for hegemony, which is played out on the terrain of common sense. This is important to CDA for two reasons: firstly, for the more obvious reason that CDA is concerned with understanding, highlighting and critiquing elements of this struggle, and secondly because (as mentioned above) common sense must be organised.

The process of organising, and struggling for control of, common sense can be related directly to two key premises of CDA: that discourse does ideological work and that power relations are discursive (Fairclough et al., 2011, p. 369-372). Focusing on the former, it is useful to think of ideology as a process which articulates together particular representations of reality, and particular constructions of identity' (Fairclough et al., 2011, p. 372). The control of discourse, framed within the organisation of common sense, addresses both the notion that discourse does ideological work and that a key component of power relations is its discursive nature. But how does this struggle take place, and how should we understand this struggle? Language is the framework within which ideologies, worldviews and class interests are represented, upheld, and reproduced (Green and Ives, 2009). Thus CDA, when related to Gramscian premises, is the tool through which the political nature of language is explicated.

The successful control of common sense is a crucial element in the development and maintenance of hegemony, exactly because it is concerned with legitimising some discourses and suppressing others (Van Dijk 1993). It is more appropriate to see common sense, rather than hegemony, as the process 'that universalises the particular' in a discursive sense because common sense can be seen as a 'collective noun' (Gramsci, 1971, p. 324-5) that is organised by sectional groups that wish to imbue the universal with their specific worldview (Ives, 2004, p. 74-75; Gramsci, 1971, p. 422; 323-43; 324-5). This is a deep process emphasising the fundamental link between hegemony and common sense, which simply is not addressed in the current CDA literature. 
In the interests of explicating this link in order to further benefit CDA scholarship, through emphasising the discursive potential of the strong link between the concepts (considering the concepts themselves are already present in much CDA literature), it is useful to introduce two further Gramscian concepts that currently barely appear in the CDA literature. These concepts - the war of position and normative and spontaneous grammars - are useful because they help sketch out the relationship between common sense and hegemony and therefore provide a framework for their deeper implementation within CDA.

\section{Introducing further Gramscian concepts into Critical Discourse Analysis}

These two concepts play different roles. Incorporating Gramsci's thinking on the War of Position acts more to provide a grounding to the critical premise of CDA, that it should challenge not just dominant discourses but dominant political structures. This should be seen as augmenting CDA's critical nature rather than a critique. To do so, the critique of language and discourse must be rooted in a coherent analysis of politics and society. The concept of normative and spontaneous grammars facilitates the highlighting and problematisation of various discursive constructions. Combined, these concepts emphasise and deepen the relevance and utility of common sense and hegemony within CDA approaches.

\section{War of Position}

The War of Position, for Gramsci, constitutes the ideological and socio-political groundwork that must be completed in developed capitalist states before a war of manoeuvre - a frontal attack on the ruling class - could be considered feasible. In some readings (e.g. Jones, 2006) the war of manoeuvre is unfeasible in highly developed capitalist states because of their strength and level of development, making the war of position central to struggle. In other readings, this process is not sequential, but rather dialectically related (Sassoon, 1987, p. 194). Either way, 'setting the agenda is half the battle' (Ives, 2004, p. 107). This is important to CDA because in order to realise any emancipatory power to the critique of discourse (Flowerdew, 2008, p. 195), the critique must at least on some level destabilise established agendas and promote new ones. Furthermore, discourse does ideological work precisely to win (or more likely to gain an advantage within) the war of position.

The war of position as related to discourse is concerned with established power structures within language itself. It is the process of controlling 'the whole organisational and industrial system of the territory which lies to the rear of the field' (Gramsci, 1971, p. 239). It is of little help seizing control of key institutions if one is hamstrung by the linguistic and discursive framing by which those institutions are understood and presented. The failed attempts by social democratic parties to firstly critique successfully and secondly make political capital (primarily in terms of electoral success) from the recent financial crisis provides a strong example of the importance of the war of position. Although the crisis provided plenty of material and impetus to argue for greater regulation and even wholesale reform of the existing market system, social democratic (and especially Third Way) parties' responses were particularly weak. In a time where centre-left parties should have been returning to power across Europe, they were being defeated convincingly by the centre and populist 
right (Ryner, 2010; 2014). Although this is certainly in part due to many such parties being in power prior to and during the crisis, it is also because the political and social language of these parties had become increasingly managerial and neo-liberal in nature, reproducing discourses that favoured the politics of the centre-right (Ross, 2014, p. 49). Although provided originally for a different context Stuart Hall (1986, p. 18), quoting Gramsci (1971, pp. 238-9), outlines what can be seen as a Gramscian linguistic critique of the above example:

In these more 'advanced' societies, 'where civil society has become a very complex structure... resistant to the catastrophic "incursions" of the immediate economic element... the superstructures of civil society are like the trench-systems of modern warfare'.

This is only one element in what is an intimidatingly large struggle. The war of position is the struggle for control of civil society, ideological apparatuses, and common sense itself - the collective will of society. This makes it inherently about gaining hegemony, yet this requires in itself an 'unprecedented concentration of hegemony' (Gramsci, 1971, p. 238). It is certainly not something that can be achieved on a discursive level alone; the discursive should be seen as one of many interlinked terrains of struggle in which the war of position is waged.

Here, discursive struggle is ideological struggle. Hall (1996, pp. 40-1) argues that powerful concepts such as democracy 'do not swing about from side to side in language or ideological representation alone'. The ideological struggle involves 'detach[ing] one meaning of the concept from the domain of public consciousness and supplant[ing] it within the logic of another political discourse'. This is the organisation of common sense, leading to the development and maintenance of hegemony. CDA is a tool in this struggle to critique and subsequently organise dominant meaning, so that it 'becomes the nucleus of a new ideological and theoretical complex' (Gramsci, 1971, p. 195).

Gramsci illustrates the process by which discourses become common sense, understood as a constituent process of the broader war of position. It highlights also that this process is a political struggle in which different blocs vie for supremacy, according more of a role on to political and social agents in this struggle.

\section{Normative and Spontaneous Grammars}

A particularly useful concept for CDA is normative and spontaneous grammar. Although having a long history within linguistics, Gramsci associates them with concerns and analyses of the dynamics and workings of political and social power. They provide a method of understanding how discourses are transmitted, internalised and reproduced at a non-elite level (Donoghue, 2016). As Ives (2004, p. 37) attests, the concept of normative grammar is 'key to Gramsci's development of hegemony'. Gramsci derives the concept from Ferdinand de Saussure in two ways: to incorporate grammatical correctness and a 'proper' way of speaking (therefore reproducing inherent power relations, usually between classes), and; situating grammar as historically specific, acknowledging that certain grammar rules are the products of specific historical moments. Important for the notion of discourse as an agent or 
vehicle of social change, normative grammar polices language in order to legitimise particular spontaneous grammars over others:

Besides the "immanent grammar" in every language, there is also in reality (i.e. even if not written) a "normative" grammar (or more than one). This is made up of the reciprocal monitoring, reciprocal teaching, reciprocal "censorship" expressed in such questions as "What did you mean to say?", "What do you mean?", "Make yourself clearer", etc., and in mimicry and teasing. This whole complex of actions and reactions come together to create a grammatical conformism, to establish "norms" or judgements of correctness and incorrectness (Gramsci, 1985, p. 180).

Normative grammar ensures the reproduction of the 'correct' spontaneous grammar. '[N]ormative grammars are produced through the organisation, codification and legitimisation of certain spontaneous grammars' (Ives, 2004, p. 96), which is a competitive process in which some spontaneous grammars are suppressed. This process can be likened to the rise of dominant discourses, which are themselves a result of competitive processes of (de)legitimisation, suppression and promotion. This also highlights the dialectical relationship between the two, and demonstrates again that the use of particular imagery, concepts and language, particularly in political and social speech, is directed by struggle on some level. Indeed, 'normative grammar amounts to the exercise of power and law (even if informal customary law, as in the case of the peasant who moves to the city) over some people' (Ives, 2006, p. 42). Therefore, spontaneous grammar is not spontaneous in terms of it simply appearing out of nowhere without any agential force. Rather it is what appears and is accepted as normal and natural, but has in fact been engineered to differing extents though the competitive process of legitimising and suppressing multiple normative grammars.

There is clear significance for CDA. Not only does the process of spontaneous grammars conform to the broader conceptualisation of common sense, but it also provides an in-depth framework for analysing discourse in multiple settings. Current CDA is well placed to critically analyse language and discourse used by elites in speeches, policy documents, press releases and so on, but it could be stronger on analysing the reproduction and challenge of discourse when used by non-elites. Incorporating normative and spontaneous grammars allows one to identify the suppression, challenging and reproduction of different discourses within subaltern voices, allowing for a picture of common sense to be built.

An example of this can be drawn from empirical work undertaken by Donoghue (2016, pp. 8-9; see also Donoghue, 2014). It demonstrates firstly how a normative grammar is constructed within New Labour policy literature on cohesion and integration, and how it then impacts upon a fieldwork participant's understanding of community and cohesion and his place and role within both.

\footnotetext{
2 'Immanent grammar' is largely used interchangeably with 'spontaneous grammar' by Gramsci. In line with Ives (2004), I use 'spontaneous grammar' throughout, considering its important relationship with spontaneous consent.
} 
The Commission on Integration and Cohesion, following on from various reports (e.g. Home Office, 2001a; 2001b) produced a report examining the UK's approach in the light of riots in northern England in 2001. It promoted:

a new emphasis on rights and responsibilities in the context of integration and cohesion - recognising that government has in the past set out this type of approach to welfare reform, for example, but that it is time to apply it as a response to local and dynamic demographic change [...] The concept of citizenship is therefore developed into something that can stand as a wider contract of rights and responsibilities for all citizens. And to get to that, we need to openly debate forms of citizenship that prioritise integration and cohesion (CIC, 2007, p. 62).

Within this extract, the construction of a normative grammar can be identified around the issue of migration and cohesion. It frames the issue in the positive language of openness and debate. Yet the parameters of the debate are closed, presenting (and thus legitimising) as the only option a very specific notion of integration. The normative grammar, through the well-trodden trope of rights and responsibilities, suggests that citizenship is not about both of these per se, rather emphasising strongly the responsibility to integrate. This amounts to assimilation (Donoghue 2014, p. 207; 2013; Ratcliffe, 2012), considering that the 'responsibility-driven society' is so prominent in the cohesion and welfare policy literature, as demonstrated in this extract. Thus, 'one would expect integration and cohesion to conform to a power relationship that favours state structures over individual or collective agency' (Donoghue, 2014, p. 207). The choice of language is political, favouring particular political interests (Ives, 2004, pp. 95-96). The normative grammar that begins to be constructed in the above example can be identified in everyday narratives, such as that from a participant from Donoghue's empirical work.

A British-Asian fieldwork participant discusses his experiences of suffering racism. He has lived in the same area all his life and therefore can be considered a member of the host community. However, many have argued that the 'host' community can be thought of as synonymous with white British, and does not extend to Muslim members of the community (Worley, 2005):

As a community or as south Asian or Muslim etcetera, we use the word discrimination, racism as an excuse sometimes. [...] I think we're more racist sometimes than the host community, about wanting to integrate, about wanting to get together - we would rather stay out of it (fieldwork participant cited in Donoghue, 2016, p. 8)

As argued by Donoghue (2016, p. 9), the participant's belonging to different communities (his neighbourhood in Bradford, his Muslim and south Asian heritage, and his Britishness), gives him authority on issues of racism. However, separating south Asian and Muslim from the designation of 'host community' emphasises otherness, and responsibilises him to 'do more' to integrate into the host community, even though he is already a member of that community. This is illustrated particularly strongly in his assertion that his community is more racist than the host community. As argued in the analysis of this extract, the 
participant 'uses normative grammar through this separation and self-accusation: he significantly reduces his ability to take a dissenting stand on matters, deligitimising his own position. He disciplines himself through his choice of language' (Donoghue, 2016, p. 9).

Although the above example demonstrates the use of normative grammar as a method of policing language and discourse, thus maintaining common sense, it can also be employed to destabilise common sense discourses. This could be found within everyday discussions and narratives, or it could also be used as a deliberate method within CDA to critique and problematize language that reproduces oppressive power relations. The principal difference between current usages of these concepts in CDA and a usage augmented by normative and spontaneous grammars is that the latter emphasises the mechanics of political and social domination via language facilitating identification and analysis of the way social power abuse, dominance, and inequality are enacted, reproduced, and resisted by text and talk in the social and political context' (Van Dijk, 2004, p. 352).

Perhaps most importantly, the inclusion of the above understanding of normative and spontaneous grammars allows for the greater inclusion of agency within discussions of discourse. Rather than suggesting that one group (e.g. elites) control the production and dissemination of discourse, the mechanics of the grammars as outlined by Gramsci emphasise struggle, outlined in this article as central to hegemony in CDA. In this struggle both dominant and subaltern groups have agency, but it is the elite groups that have historical, social and political structures on their side. Yet identifying and analysing this explicitly facilitates exposing dominance through language, whilst also uncovering the way in which such dominance comes about. This provides a more forceful problematisation and critique, opening space for greater challenges and alternative populations of meaning.

Using normative and spontaneous grammars as explanatory concepts links to wider theoretical concerns on the war of position. If Gramsci's use of grammars can contribute to the more forceful critique of current discourses and by extension a clearer understanding and critique of class relations via language, it can contribute to bolstering the position of subaltern classes and progressive forces within the war of position. Thus, these concepts clearly contribute to the explicit social and political critique that is expected from CDA.

\section{Conclusions}

CDA is not tied to one specific theory and is thus free to choose and combine a great many elements from different perspectives, though usually from within the broad critical canon. However, the approach's malleability can lead to a lack of conceptual clarity that potentially hinders 'the original self-declared emancipatory mission of CDA, the ability of CDA to at least contribute to the betterment of society and liberation of individuals' (Chilton and Wodak, 2005, p. xv). The systematic incorporation of Gramscian concepts such as the war of position and the use of normative and spontaneous grammars is not the only option open to scholars of CDA, considering its flexible nature. However considering the ostensible importance of concepts such as hegemony and common sense, particularly in the CDA associated with Fairclough, their inclusion enables a much deeper appreciation of these concepts and their significance to the overall approach of CDA. 
Highlighting the extended benefits for CDA of engaging more closely with Gramsci's work has underlined the problems associated with providing only a cursory discussion of hegemony and common sense. It has demonstrated a number of pitfalls, such as the conflation of hegemony and common sense as performing increasingly similar tasks. Though the two concepts are of course co-constitutive, they play very different roles, and this should be acknowledged within CDA scholarship. Yet a greater understanding of the significance of these concepts in the enhancing of CDA can only come about through engaging with other concepts key to the linguistic elements of Gramsci's work. Undertaking such an endeavour may result in CDA becoming somewhat more rigid than a number of scholars may prefer, but it also provides a well-defined, socially situated critical framework within which processes of domination and inequality in talk and text can be identified and situated within wider analyses of ideational and material struggle. A central draw of CDA will always be its impressive ability to draw inspiration from the full range of critical theories, and this should not change. However, as this article has demonstrated, CDA can be greatly enriched by engaging more deeply with the work of thinkers such as Gramsci.

\section{References}

Bieler, A., Morton, A.D. (2008), The Deficits of Discourse in IPE: Turning Base Metal into Gold? International Studies Quarterly 52: 103-128

Blommaert, J. (2005), Discourse: a critical introduction. Cambridge: Cambridge University Press

Blommaert, J., Bulcaen, C. (2000), Critical Discourse Analysis. Annual Review of Anthropology 29: 447-466

Breeze, R. (2011), Critical Discourse Analysis and its Critics. Pragmatics 21(4): 493-525

Burnham, P., Gilland Lutz, K., Grant, W., Layton-Henry, Z. (2008) Research Methods in Politics (2nd Ed.). Basingstoke: Palgrave

Chilton, P., Wodak, R. (2005) "Preface", in Wodak, R., Chilton, P. (Eds.), A New Agenda in (Critical) Discourse Analysis: Theory, Methodology and Interdisciplinarity. Philadelphia: John Benjamins. Pp. xixii

De Goede, M. (2003), Beyond Economism in International Political Economy. Review of International Studies 29(1): 79-97

De Goede, M. (2005), Virtue, Fortune, and Faith: A Genealogy of Finance. Minneapolis, MN: University of Minnesota Press

Donoghue, M. (2014), Cohesion in the context of Welfare and Citizenship: Discourse, Policy and Common Sense. PhD Thesis: Oxford Brookes University

Donoghue, M. (2016), 'Cohesion' as common sense: Everyday Narratives of Community and Cohesion in New Labour's Britain. Politics 36(3): 262-276

Fairclough, N. (1985), Critical and descriptive goals in discourse analysis. Journal of Pragmatics 9(6): 739-763

Fairclough, N. (1989), Language and Power. London: Longman 
Fairclough, N. (1992) Discourse and Text: Linguistic and Intertextual Analysis within Discourse Analysis. Discourse and Society 3(2): 193-217

Fairclough, N. (2001), "Critical discourse analysis as a method in social scientific research". In Wodak, R., Meyer, M. (Eds.). Methods of Critical Discourse Analysis. London: Sage. Pp: 121-138

Fairclough, N. (2003), Analysing Discourse: Textual Analysis for Social Research. London: Routledge Fairclough, N. (2004), Critical discourse analysis and critical policy studies. Critical Policy Studies 7(2): 177-197

Fairclough, N., Muldering, J., Wodak, R. (2011), "Critical Discourse Analysis". In Van Dijk, T.A. (Ed.), Discourse Studies: A Multidisciplinary Introduction. London: Sage

Fairclough, N. (2013), Critical Discourse Analysis: The Critical Study of Language. $2^{\text {nd }}$ ed. London: Routledge

Flowerdew, J. (2008), "Critical discourse analysis and strategies of resistance". In Bhatia, V.K., Flowerdew, J., Jones, R.H. (Eds.), Advances in Discourse Studies. London: Routledge. Pp: 195-210

Fowler, R. (1996), "On critical linguistics". In Caldas-Coulthard, C.R., Coulthard, M. (Eds.), Texts and Practices: Readings in Critical Discourse Analysis. Pp: 3-14

Gough, V., Talbot, M. (1996), "'Guilt over games boys play': Coherence as a focus for examining the constitution of heterosexual subjectivity on a problem page". In Caldas-Coulthard, C.R., Coulthard, M. (Eds.), Texts and Practices: Readings in Critical Discourse Analysis. Pp: 214-230

Gramsci, A. (1971) Selections from the Prison Notebooks. Translated by Quentin Hoare and Geoffrey Nowell Smith. New York: International Publishers

Gramsci, A. (1985) Selections from Cultural Writings. Translated by David Forgacs and Geoffrey Nowell Smith. Boston: Harvard University Press

Green, M.E., Ives, P. (2009), Subalternity and Language: Overcoming the Fragmentation of Common Sense. Historical Materialism 17: 3-30

Hall, S. (1986), Gramsci's Relevance for the Study of Race and Ethnicity. Journal of Communication Inquiry 10: 5-27

Hall, S. (1996), "The problem of ideology: Marxism without guarantees". In Morley, D., Chen, K-H (Eds.), Stuart Hall: Critical Dialogues in Cultural Studies. London: Routledge: pp. 24-45

Herman, E.S., Chomsky, N. (1988), Manufacturing Consent: The Political Economy of the Mass Media. New York: Pantheon Books.

Hook, D. (2001), Discourse, knowledge, materiality, history: Foucault and discourse analysis. Theory and Psychology 11(4): 521-547

Ives, P. (1997), The Grammar of Hegemony. Left History 5(1): 85-104

Ives, P. (2004), Language and Hegemony in Gramsci. London: Pluto

Ives, P. (2005), Language, Agency and Hegemony: A Gramscian Response to Post-Marxism. Critical Review of International Social and Political Philosophy. 8(4): 455-468 
Ives, P. (2006), Gramsci's Politics of Language: Engaging the Bakhtin Circle and the Frankfurt School. Toronto: University of Toronto Press

Jessop, B. (1990), State Theory: Putting the Capitalist State in its Place. Pennsylvania: Penn State Press

Jessop, B. (1997), "A neo-Gramscian approach to the regulation of urban regimes", in Lauria, M. (Ed.), Reconstructing Urban Regime Theory. London: Sage. Pp: 51-73

Jones, S. (2006), Antonio Gramsci. London: Routledge

Jorgensen, M., Phillips, L.J. (2002), Discourse Analysis as Theory and Method. London: Sage

Kincheloe, J. L., McLaren, P. (2002)." Rethinking Critical Theory and Qualitative Research". In Zou, Y, Trueba, E.T. (eds.) Ethnography and Schools. Roman and Littlefield. pp. 87-96

Laclau, E. (2005), On Populist Reason. London: Verso

Laclau, E., Mouffe, C. (2001), Hegemony and Socialist Strategy: Towards a Radical Democratic Politics ( $\left.2^{\text {nd }} E d.\right)$. London: Verso

Leggett, W. (2009) 'Prince of modernisers: Gramsci, New Labour and the meaning of modernity', in McNally, M., Schwarzmantel, J. (eds.) Gramsci and Global Politics: Hegemony and Resistance, London: Routledge

Locke, T. (2004), Critical Discourse Analysis. London: Continuum

Luke, A. (1995), "Text and discourse in education: An introduction to critical discourse analysis." In Apple, W.M. (Ed.), Review of research in education Vol 21. Washington DC: American Educational Research Association. Pp: 3-48

Luke, A. (2002), Beyond Science and Ideology Critique: Developments in Critical Discourse Analysis. Annual Review of Applied Linguistics 22: 96-110

Morton, A.D. (2007), Unravelling Gramsci. London: Pluto

Phillips, N., Hardy, C. (2002) "Discourse Analysis: Investigating Processes of Social Construction", Sage University Papers Series on Qualitative Research Methods, Vol. 50. Thousand Oaks: Sage

Ross, G. (2014), "Social democracy and social movements from crisis to crisis". In Bailey, D.J., De Waele, J., Escalona, F., Vieira, M. (Eds.), European social democracy during the global economic crisis: Renovation or resignation? Pp. 42-59

Rupert, M. (2003) Globalising common sense: a Marxian-Gramscian (re-)vision of the politics of governance/resistance. Review of International Studies. 29 (S1): 181-198

Ryner, M. (2010), An Obituary for the Third Way: The Financial Crisis and Social Democracy in Europe. The Political Quarterly 81(4): 554-563

Ryner, M. (2014), "Why the financial crisis has not generated a social democratic alternative in Europe?". In Bailey, D.J., De Waele, J., Escalona, F., Vieira, M. (Eds.), European social democracy during the global economic crisis: Renovation or resignation? Pp. 60-76

Sassoon, A.S. (1987), Gramsci's Politics. London: Hutchinson 
Sassoon, A.S. (2000), Gramsci and Contemporary Politics: Beyond Pessimism of the Intellect. London: Routledge

Slembrouck, S. (2001), Explanation, interpretation and critique in the analysis of discourse. Critique of Anthropology 21: 33-57

Thomas, P.D. (2013) Hegemony, Passive Revolution and the Modern Prince. Thesis Eleven 117 (1): 20-39

Van Dijk, T.A. (1993), Principles of Critical Discourse Analysis. Discourse and Society 4(2): 249-283

Van Dijk, T.A. (2001), "Multidisciplinary CDA: a plea for diversity” in Wodak, R., Meyer, M (Eds.), Methods of Critical Discourse Analysis. London: Sage. Pp. 95-120

Van Dijk, T.A. (2006), Ideology and Discourse Analysis. Journal of Political Ideologies 11(2): 115-140

Wodak, R. (2001), "What CDA is about - a summary of its history, important concepts and its developments". In Wodak, R., Meyer, M (Eds.), Methods of Critical Discourse Analysis. London: Sage. Pp. 1-13

Wodak, R., Meyer, M. (2009), "Critical Discourse Analysis: History, Agenda, Theory, and Methodology". In Wodak, R., Meyer, M. (Eds.), Methods of Critical Discourse Analysis. London: Sage pp. 1-13 